\title{
Hvordan integreres teknologiforståelse i dansk?
}

\author{
Af Marie Falkesgaard Slot, \\ Rasmus Fink Lorentzen \\ og Thomas Illum Hansen
}

Korrekt citering af denne artikel efter APA-systemet (American Psychological Association System, 7th Edition): Slot, M. F., Lorentzen, R. F. \& Hansen, T. I. (2021). Hvordan integreres teknologiforståelse i dansk? Learning Tech - Tidsskrift for læremidler, didaktik og teknologi, (10), 21-46. DOI 10.7146/It.v6i10.122751 
Artiklen undersøger med udgangspunkt i det igangværende Forsøg med teknologiforståelse (UVM, 2018-2021), hvordan forsøget på at integrere teknologiforståelse i dansk rammesættes i styredokumenter (Fælles Mål, læseplan og undervisningsvejledning) og didaktiseres i udvalgte undervisningsforløb. Det empiriske grundlag for artiklen er dokumentstudier af læreplaner og forløb.

På et generelt niveau konkluderer undersøgelsen, at udfordringerne med at integrere dansk og teknologiforståelse hænger sammen med forskelle i såvel fagforståelser og begrebsbrug som i fagenes metoder og praksis. På et konkret niveau undersøges det via analyser af læreplaner og udvalgte forløb, hvordan danskfagets tekstbegreb og analysemetoder udfordres, når man bl.a. analyserer robotter som tekster, forsøger at navigere mellem forskellige måder at begrebsliggøre digital dannelse og myndiggørelse på samt beskæftiger sig med meget basale betingelser for produktion, brug og udveksling af data som del af en digital kommunikation.

In this paper, the ongoing Experiment with Technology Comprehension (UVM) is analyzed in order to understand how technology comprehension is integrated into Danish as subject on a curriculum level and on a learning design level. The empirical basis for the analysis are studies of the official documents on curricula level (curriculum and syllabus) and of selected learning designs in Danish as a subject.

On a general level, the study concludes that the challenges of integrating the subject and technology comprehension are related to differences in both professional understandings and terminology and in the applied methods and actions. On a specific level, the analysis of both the syllabus and the learning designs indicates that both the perceptions of texts and the analytical methods are challenged. This is the case when robots are introduced as subject matter and when teachers have to navigate between digital empowerment and more basic conditions for production, use and data exchange as part of digital communication in the subject of Danish. 


\section{Hvordan integreres teknologiforståelse i dansk?}

\section{Teknologiforståelse - et nyt fag og en ny faglig- hed i skolen}

I disse år udvikles og afprøves en ny faglighed i folkeskolen ved navn teknologiforståelse. Denne faglighed har især afsæt i datalogi og informatik, og det er en større diskussion, hvorvidt den skal fortolkes inden for rammerne af STEM-fagligheden eller endnu bredere STEAM-fagene. Fortolkningen af den nye faglighed er præget af en række toneangivende eksperter med viden om især science, teknologi og designtænkning, blandt andet inden for gymnasieområdet (Iversen, 2019; Caspersen, Iversen, Nielsen, Hjorth \& Musaeus, 2018). Teknologiforståelse blev præsenteret i Undervisningsministeriet i foråret $2018 \mathrm{som}$ et selvstændigt fag. Samme år satte UVM et treårigt afprøvningsforsøg i gang på 46 danske grundskoler fra 1. klasse - 9. klasse, hvis formål er at afprøve den nye faglighed. Ud over det selvstændige fag er teknologiforståelsesfagligheden forsøgsvis integreret i syv skolefag med henblik på at undersøge, hvordan teknologifagligt indhold kan integreres i eksisterende fag; et af disse fag er dansk. Formålet med denne artikel er at undersøge muligheder og udfordringer i udviklingen af teknologiforståelse i dansk med afsæt i styredokumenternes bud på en rammesætning og forsøgsprogrammets bud på en didaktisering af teknologiforståelse som danskfagligt indhold.

I Danmark blev begrebet teknologiforståelse udbredt med det 5 -årige forsknings $\neg$ projekt Technucation (2011-2015). Technucation er relevant i denne sammenhæng, fordi det undersøgte læreres teknologiforståelse og knyttede begrebet til udøvelse af en profession. Projektets arbejdsdefinition på teknologiforståelse var således:

1 STEM anvendes på engelsk som akronym for Science, Technology, Engineering, Mathematics. STEAM med tilføjelsen af Art. 
Den tillærte evne til at tilegne sig og kombinere teknisk handleviden med andre former for social og kulturel forståelse, som gør professionsuddannede i stand til at hjælpe hinanden med at identificere og kvalificere muligheder for brug, anvendelse og innovation af og alternativer til teknologiske løsninger, der forandrer praksis i en professionskontekst.

(Haase \& Andersen, 2012, s. 23)

I forbindelse med Technucation blev der gennemført et review med fokus på policy-litteratur og forskning i relation til det beslægtede begreb på engelsk "technological literacy" (Wallace, 2011), og på den baggrund kunne projektet tegne et billede af de internationale tendenser. Disse var især knyttet til STEM-fag og bestræbelser på at udvikle og implementere standarder på tværs af disse fag som en ny form for teknologi-faglighed (ITEA, 2000 \& 2007). ITEA (International Technology Education Association) definerer denne faglighed som en kapacitet til at anvende, styre, evaluere og forstå teknologi (ITEA, 2007, s. 9), men standarderne rummer også et perspektiv på hverdagslivet: "A technologically literate person understands the significance of technology in everyday life and the way in which it shapes the world" (ITEA, 2007, s. 33). Det er dette antropologiske perspektiv, der blev styrket med Technucation-projektet. I stedet for at definere teknologiforståelse som STEM-faglighed alene med tilhørende standarder og kompetencer, vægtede projektet udviklingen af fortrolighed med teknologi i menneskets livsverden (Ihde, 2010) samt det menneskelige samspil med teknologier (Dakers, 2005; Ingerman \& Collier-Reed, 2011; Hasse \& Andersen, 2012). Teknologier opfattedes ikke kun som nyttebetonede redskaber, men som indgribende agenter eller aktører.

Technucation-projektet markerede et nybrud i tilgangen til teknologi og var med til at henlede opmærksomheden på, at den teknologiske udvikling skaber et behov for fagligt kvalificerede begreber og analyser af samspillet mellem menneske og teknologi. Denne kritiske opmærksomhed var ikke blot et videnskabsfagligt anliggende, men blev en del af den politiske offentlighed og i forlængelse heraf en væsentlig begrundelse for, at man sidenhen har udviklet teknologiforståelse som selvstændigt fag (UVM, 2019a; UVM, 2019b).

\section{Den nye faglighed teknologiforståelse}

Det selvstændige fag er bygget op om fire kompetenceområder: "Digital myndiggørelse", "Digital design og designprocesser", "Computationel tankegang" og "Teknologisk handleevne" (UVM, 2018, s. 10-13; Caspersen, Iversen, Nielsen, Hjorth \& Musaeus, 2018). 
I fagligheden har man prioriteret designtænkning som en privilegeret tilgang til teknologiforståelse. Idéen synes at være, at elever udvikler teknologiforståelse ved at tage udgangspunkt i kendte teknologier, analysere dem og komme med bud på, hvordan man kan redesigne dem. Derudover lægger designtænkning op til, at eleverne selv skal udtænke og designe nye teknologier.

Et eksempel på et centralt videns- og færdighedsmål er "Konsekvensvurdering” af digitale artefakter, der sætter fokus på teknologiers betydning for individ, fællesskab og samfund. Et væsentligt mål, men det er symptomatisk for fortolkningen af den nye faglighed, at det ikke under $\neg$ støttes af humanistiske tilgange i læreplanen, der ellers ville muliggøre en bredere teknologiforståelse ved hjælp af eksempelvis historiske perspektiver, sammenlignende kulturstudier, sociologiske problematiseringer, fiktive fremstillinger eller filosofisk behandling af etiske dilemmaer.

Det bemærkes tillige, at teknologi som begreb ikke defineres i styredokumenterne. Som nævnt lægges der vægt på at udvikle digitale artefakter, men uden at det defineres, hvad et digitalt artefakt er, eller hvilken videnskabelig tradition, der ligger til grund for begrebet. Artefaktbegrebet i styredokumenterne for teknologiforståelse fremstår derfor flertydigt, fordi det hverken defineres eller forankres i en bestemt teoretisk tradition.

\section{Integration af en ny faglighed}

Gennem skolefagenes historie har det været en tilbagevendende opgave at integrere nye fagligheder. Fx var "Det grønne islæt" i 2000-2001 et presserende tema, som skulle give mulighed for fagligt og tværfagligt samspil omkring miljø og drivhuseffekt, som det hed dengang. I de fleste tilfælde har nye og ofte fagudviklende del-fagligheder ikke taget afsæt i eksisterende fag eller nye fag, men har været fælles epokale nøgleproblematikker, som de eksisterende skolefag skulle udfolde med afsæt i faglige systematikker.

Teknologiforståelse adskiller sig ved både at være formuleret som en ny faglighed og samtidig være en nøgleproblematik, der skal integreres i fagene, fordi den vedrører menneskehedens omgang med teknologi i en epoke i verdenshistorien, hvor computerens udvikling og anvendelse har gennemgribende betydning for alle dele af samfundet. Teknologiforståelse som faglighed bliver derfor en anledning til at undersøge, hvilke indholdsområder der kan bidrage til en øget forståelse af teknologiens betydning og rolle i skolefaget dansk, og hvilke fagdidaktiske problemstillinger der skal udvikles for at forstå hvorfor, med hvad og hvordan fagligheden kan integreres i fagets eksisterende mål. 
Det er derfor relevant at undersøge de styredokumenter, det vil sige tillæg til Fælles Mål, Læseplan for dansk samt Læsevejledning, UVM har udviklet til dansk, og subsidiært de fremstillede undervisningsforløb, som i forsøget benævnes prototyper. Vores antagelse er, at styredokumenternes fortolkning af den nye faglighed bør revideres og kvalificeres med afsæt i en humanistisk tilgang til teknologi som en integreret del af menneskets livsverden. En humanistisk udvidelse af tilgangen til teknologi er en forudsætning for en meningsfuld kobling af teknologiforståelse som ny faglighed og dansk som fagtradition. Det bør dog bemærkes, at vi samtidig ser et potentiale i en gensidig berigelse, da teknologiforståelse dels kan være didaktisk anledning til en genfortolkning af danskfagets mål, indhold og metoder, og dels kan blive beriget med danskfaglige perspektiver på både praktisk-kommunikativ brug og æstetisk-fortolkningsmæssig oplevelse af teknologi.

Hvis vi genkalder os nogle af de genstandsfelter og delfagligheder, som tidligere er blevet integreret i dansk, er eksemplerne blandt andet, at det, vi inden for faget betegner med overordnede termer som dels it og medier, dels multimodalitet og literacy, har været med til at ændre fagets indhold og stofområder (Hansen, 2015; Elf, 2017). Her er det for omfattende at gå ind i, hvordan og på hvilke måder dette er sket, men karakteristisk er, at der er tale om indholdselementer, man har kunnet fortolke som fagligt legitime og meningsfulde inden for rammerne af dansk som et fortolknings- og kommunikationsfag. Med den nye teknologifaglighed er det anderledes; teknologi optræder fire gange i den oprindelige læseplan, og det sker altid i forbindelse med området it og kommunikation:

\section{9}

Undervisningen omfatter brugen af digital teknologi i kommunikationssituationer i hverdagen og modtagerrettet kommunikation. Undervisningen bør fokusere på kombination af modaliteterne ord, billede og lyd og på variation af disse.

(UMV, 2019a, s. 7)

Der er langt fra en forståelse af teknologi som et redskab eller et værktøj til brug i kommunikation til den nye teknologifaglighed. Teknologi oversættes oftest i fagdidaktiske tekster til fx redskaber til kommunikation, digitale tekster og medier og digitalisering. Den danske udgave af ICILS-undersøgelsen har i den seneste udgave undersøgt elevers teknologiforståelse som en del af deres it-kompetencer. Derfor findes her en del resultater omhandlende elevers brug af teknologi og holdninger til egne kompetencer (Bundsgaard, Bindslev, Caeli, Pettersson 
\& Rusmann, 2019) (Bundsgaard, Petterson \& Puck, 2014). Derimod er begrebet teknologiforståelse som sådan ikke slået igennem endnu i skolefagets praksis. På baggrund af ovenstående indkredsning er vi derfor interesserede i at undersøge det aktuelle forsøg på at integrere teknologiforståelse som indhold i læreplanen for dansk og fortolkningen heraf, som den materialiseres i udvalgte undervisningsforløb til folkeskolen, hvorfor vi formulerer følgende forskningsspørgsmål:

\section{På hvilke måder rammesættes integrationen af teknologi-} forståelsesfagligheden i dansk i styredokumenter, dvs. Tillæg til Fælles Mål, Læseplan og Undervisningsvejledning for dansk, og hvordan didaktiseres teknologiforståelsesfagligt indhold i undervisningsforløb tilknyttet afprøvningsfors $\emptyset$ get i teknologiforståelse i dansk i folkeskolen?

\section{Metode og undersøgelsesdesign}

Artiklen bygger derfor på dokumentanalyse af to typer af dokumenter: De foreløbige udkast til styredokumenter for dansk, der blev nævnt i ovenstående, og to eksempler på undervisningsforløb i dansk, som er udviklet til Forsøg med teknologiforståelse.

Dette empiriske materiale bliver analyseret som del af en større kontekst: Afprøvningsforsøget som helhed og det omfattende review-arbejde, der indgik som en metodisk integreret del af forsøget (Rambøll, 2019). Mikala Hansbøl og Marie Slot stod således i spidsen for en review-proces, der omfattede i alt 108 forløb i afprøvningsfors $\emptyset$ get, heraf 18 i dansk (derudover indgår dansk i fire tværfaglige forløb). Der er udarbejdet review af alle forløb med følgende opmærksomhedspunkter:

— teknologibegrebet i forløbet,

- sprog og begrebsbrug,

- progression,

— elevcentreret læring,

— komplekse problemstillinger,

- differentiering og

- evaluering.

2 ICILS står for International Computer and Information Literacy Study og er en international sammenlignende undersøgelse af 8. klasses elevers it-kompetencer. 
Det samlede review tilvejebringer et første overblik over, hvordan teknologiforståelse som faglighed fortolkes inden for rammerne af forsøgsprogrammet. På den baggrund har vi valgt de to forløb i dansk, som stammer fra 1. og 2. afprøvningsfase, ud fra et ønske om at belyse, hvad der sker, når den nye faglighed skal integreres i en etableret faglighed. Det bagvedliggende selektionskriterie kan sammenfattes som et valg af usædvanlige cases, hvor grænserne for gængs praksis i dansk udfordres mest muligt (Flyvbjerg, 2010, s. 474). På baggrund af resultaterne af casestudierne, fortolker vi dem som ekstreme cases. Man kunne også argumentere for, at der var tale om kritiske cases, da det er vanskeligt at integrere fagligheden på trods af en større indsats med ekstra ressourcer og involvering af didaktiske konsulenter. Heri ligger et større potentiale for generalisering, hvis man på den baggrund kan udlede, at man ikke kan integrere teknologiforståelse i dansk, herunder især ikke i en daglig praksis, hvor der ikke er ekstra ressourcer. Vi vælger dog at tolke de to cases som ekstreme, da vi ikke mener, at mulighederne for at integrere og genfortolke teknologiforståelse som faglighed er udtømte.

Den første case er forløbet: Kan man voere ven med en robot? Casen er ekstrem, selv om den også rummer et kritisk potentiale. På mange måder lykkes det at rammesætte et fokus på litteratur og teknologi, der er meningsfuld inden for en danskfaglig optik, men de faglige elementer fra teknologiforståelse er ikke desto mindre for fremmedartede og vanskelige at integrere.

Den anden case er forløbet: Dage med data. Casen er ekstrem, fordi den sætter fokus på ret basale betingelser for kommunikation i et digitaliseret samfund, der dels har en teknisk karakter og dels knytter an til samfundsfaglige temaer som fx overvågning og markedsgørelse. For en umiddelbar betragtning bidrager forløbet med indblik i mulighedsbetingelser for digital kommunikation, der har en vis danskfaglig relevans. Udfordringen er, at det kræver en del mellemregninger at forbinde generel viden om data og sikkerhed med konkrete kommunikationssituationer i dansk. Derfor er der tale om en ekstrem case, der har et begrænset generaliseringspotentiale, men den rummer også et kritisk potentiale. Den kan bl.a. bruges til at eksemplificere grænserne for, hvad der lader sig genfortolke inden for danskfagets rammer, og så rummer den ansatser til, hvordan man i et videre perspektiv kan arbejde tværfagligt med datasikkerhed i dansk og samfundsfag.

Metodisk har vi arbejdet med line-by-line-analyse af ovenstående dokumenter (Creswell, 2008). Både styredokumenter og forløb er blevet nærlæst på sætningsniveau med henblik på at forstå de begreber og antagelser om sammenhænge, som udtrykkes heri. Dette indhold har vi løbende sammenholdt med vores egen viden om og forståelser af danskfagets historik og danskfaglighed. Der er således tale om en 
hermeneutisk tilgang, hvor analysen er blevet til i vekselvirkningen mellem beskrivelser af den nye faglighed og vores egne forforståelser af danskfaget (Gadamer, 2007, s. 285).

I vores dokumentstudier er vi især optaget af, hvilke valg der er truffet i forhold til, hvilken faglighed der kommer til syne i måloversigt, læreplan og undervisningsvejledning, og hvordan disse valg kan tænkes at få betydning for skolefagenes praksis. En kortlægning af styredokumenterne for teknologiforståelse gør det muligt at rette et fagdidaktisk blik på teknologiforståelsesfagligheden i fagene, men under hensyntagen til at teknologiforståelsesfagligheden ikke er udviklet i samme grad som etablerede fagligheder. Det betyder også, at man med en vis ret kan problematisere, om der allerede nu kan etableres et fagdidaktisk blik på teknologiforståelse, når faget og fagligheden er under afprøvning, og når der reelt ikke findes en velbeskrevet praksis i skolen (Krogh, Qvortrup \& Christensen, 2016). Der er således ikke tale om en realiseret fagdidaktik, men om en didaktik som udvikles i flere led gennem læseplan, undervisningsvejledning og konkrete forløb. Som van den Akker, Kuiper \& Hameyer (2003) har argumenteret for, så foreskriver styredokumenterne en didaktisk praksis. Vores analyse tegner derfor konturerne af en fagdidaktik in spe, der er intenderet $\mathrm{i}$ styredokumenterne og aktualiseret med forløbenes didaktiske fortolkning af mulige realiseringer.

\section{Analyse af styredokumenter: Teknologiforståel- sesfaglighed i dansk}

Teknologiforståelse som faglig dimension i dansk tager form efter teknologiforståelse udviklet som selvstændigt fag. Det rejser et spørgsmål om, hvad der tæller som grundlæggende væsentligt indhold i en danskfaglig tilgang til teknologi. Efter redegørelsen for teknologiforståelse som fag, følger her en analyse af styredokumenterne for teknologiforståelse i dansk. Den nye faglighed blev med Forsøg med teknologiforståelse integreret i fagene dansk, matematik, natur/teknologi, fysik/kemi, billedkunst, håndværk og design samt samfundsfag (UVM, 2018). I det følgende behandles kun dansk. Teknologiforståelse i dansk består af kompetenceområderne digital myndiggørelse og digitalt design og designprocesser. Derudover inddrages enkelte mål fra teknologisk handleevne omkring digital sikkerhed.

I det følgende undersøger vi først integrationen af en ny faglighed i dansk som helhed, hvorefter vi kigger nærmere på henholdsvis design og designprocesser, digital myndiggørelse og digital sikkerhed som selvstændige områder. 
I præamblen til danskfaget står der, at teknologiforståelses-faglighed i dansk er:

\section{9}

[...] en delmængde af en noget større faglighed, som samlet set har til formål at danne og uddanne eleverne til at deltage som aktive, kritiske og demokratiske borgere i et digitaliseret samfund.

(UVM, 2019b, s. 4)

At integrere en delmængde i danskfaget af en noget større faglighed synes at være en vanskelig opgave. Formuleringen fra læseplanen lægger op til, at udviklingen af den nye faglighedsforståelse i dansk skal ske i en parallelbevægelse eller pendulering mellem de udvalgte kompetencer fra det selvstændige fag og de danskfaglige kompetencer, som færdigheds- og vidensmål vedrørende teknologiforståelse er indlejret i.

\section{Design og designtænkning}

I Dansk. Måloversigt udpeges, som nævnt, tre videns- og færdighedsmål fra kompetenceområderne "Digital design og designprocesser" og "Digital myndiggørelse" samt "Digital sikkerhed". I oversigten over færdigheds- og vidensmål efter 2. klasse er få videns- og færdighedsmål integreret fra kompetenceområdet "digital design og designprocesser". I kompetenceområdet for dansk fremstilling er digital design og designprocesser integreret (UVM, 2019a, s. 18). I kompetenceområdet for dansk kommunikation er der tale om tre videns- og færdighedsmål: Digitalt design og designprocesser, digital myndiggørelse og efter 4. kl. digital sikkerhed knyttet til kompetenceområdet for kommunikation (UVM, 2019a, s. 18). Som nævnt, spiller designtænkningen en særlig rolle i form af en elevcentreret tilgang, hvor eleverne arbejder med digital fabrikation og design med det mål at blive kritiske og konstruktive borgere (Smith, Iversen \& Hjort, 2015). Designtilgangen kan på overfladen minde om de didaktiske tilgange, vi kender fra procesorienterede skriveforløb i danskfaget. Her skal eleverne udarbejde tekster fra idé til færdigt resultat gennem flere gennemskrivningsfaser. Fælles med designtænkningen er, at begge tilgange bygger på et princip om udvikling gennem iterative processer.

En række nye begreber er med til at definere, hvordan designfagligheden skal slå igennem som løftestang for indholdsudvikling og elevinddragelse i det eksisterende fag. I læseplanen er de tre færdigheds- og vidensmål beskrevet: 
Digital design og designprocesser omhandler tilrettelæggelse og gennemførelse af en iterativ designproces under hensyntagen til en fremtidig brugskontekst. Eleverne lærer at rammesætte komplekse problemstillinger med henblik på at tilrettelægge, gennemføre og argumentere for design af egne digitale artefakter.

(UVM, 2019a, s. 8)

Læseplanen definerer ikke begreberne og udfolder ikke, hvordan de skal sættes i forbindelse med hinanden i dansk, hvilket kan skyldes, at flere af begreberne ikke umiddelbart taler sammen med typiske begreber i dansk, fx iteration, brugskontekst og digitale artefakter. Det er derfor centralt, hvordan disse nye begreber i dansk bliver omsat til en didaktisk praksis i samspil med fagets øvrige faglige metoder og begreber.

Eksempler på en didaktisk fortolkning af disse problemstillinger kan iagttages i de prototyper, som er blevet udviklet i forsøgsfaget. Her har fagudviklerne arbejdet med at oversætte de forskellige begreber og sammentænke faglighederne. Det kan eksempelvis dreje sig om proces- og produktskabelse, modtagerbevidsthed samt tekst og kontekst. På den måde forsøger fagudviklerne at imødekomme de intentioner med styredokumenterne for dansk, der fremgår af tillæg til læseplanen: "Danskfaget bidrager med mange metoder, færdigheder og kompetencer, som eleverne direkte kan overføre til arbejdet med de gennemgående tværfaglige forløb i teknologiforståelse" (UVM, 2019b, s. 9).

Danskfaget skal altså levere de kompetencer og metoder, som skal anvendes i arbejdet med teknologi, uden at man dog angiver hvilke. Derfor er tillægget ikke specielt vejledende. Arbejdet med at integrere faglighederne er overladt til praksis og til det aktuelle forsøg med teknologiforståelse uden videre handleanvisninger.

\section{Digital myndiggørelse}

Et andet nyt fagligt element er kompetenceområdet digital myndigg $\emptyset$ relse, som beskrives således: "Digital myndiggørelse består inden for teknologiforståelsesfagligheden af en række enkeltdele: Teknologianalyse, formålsanalyse, brugsstudier, konsekvensvurdering og re-design" (UVM, 2018, s. 7). Disse analytiske tilgange skal forstås ud fra et større perspektiv, idet teknologiforståelsesfagligheden har som mål, at eleverne lærer at: "[...] forstå digitale artefakters betydning i hverdags- og arbejdslivet og til at vurdere artefaktets betydning for individ, fællesskaber og samfund" (UVM, 2018, s. 19-20). 
Med begreber som teknologianalyse, formålsanalyse, brugsstudie m.fl. peger læseplanen nye steder hen i faget: dels er formålet med at analysere teknologier at opnå en form for handlekompetence, og dels skabes der i det teknologifaglige tekstarbejde nye muligheder for at tematisere kritiske vinkler på teknologi og samfund. Hensigten med disse typer af analytiske tilgange er, at afkodning og konsekvensvurdering kan udvikle elevers dømmekraft i forhold til at vurdere teknologiens betydning og konsekvenser. En tydelig ambition for faget er imidlertid også, at elever skal lære "ikke blot gennem analyse, men i høj grad også gennem deres egne erfaringer med at designe og skabe digitale artefakter" ved at have "fingrene i teknologien" (UVM, 2019b, s. 7). Det rejser spørgsmålet om, hvad et danskfagligt relevant indholdsvalg er. Hvad er det, eleverne skal erfare ved at have fingrene i teknologien? Set i vores optik udvikles og kvalificeres et danskfagligt indholdsvalg ikke med ordvalg som disse, fordi det forbliver uklart, hvilket indhold der er relevant, når eleverne i faget "skal have fingrene i teknologien". Skal eleverne fx erfare, at produktion af digitale artefakter er en form for kommunikation eller en æstetisk frembringelse, der kan sammenlignes med andre typer af tekster i dansk - og hvad vil det egentlig sige? Hvad er sammenligningens grundlag, og hvordan kan det legitimere, at artefaktet tæller som et danskfagligt kvalificeret indhold?

\section{Det samme som digital dannelse i dansk?}

Danskfaget har tradition for at forholde sig til digital dannelse, og man kan spørge, hvordan digital myndiggørelse adskiller sig fra dette? Digital dannelse, har fyldt meget i debatten om skolens rolle i forhold til børn og unges hverdagsliv med digitale medier (se Bundsgaard, 2017). Begrebet handler ifølge Bundsgaard om at anvende og opføre sig ansvarligt over for andre med teknologi (fx ansigtsløs kommunikation, som foregår løsrevet fra tid og rum); deltage engageret i debatten om teknologiers muligheder og udfordringer, både i et individ- og i et samfundsperspektiv, og om at erkende, at teknologier spiller en stadig vigtigere rolle i vores fælles liv (Bundsgaard, 2017, s. 12). Sidstnævnte betoner erkendelsesaspektet og synes dermed at pege frem mod en digital myndiggørelse, hvor idéen også er, at eleverne skal erkende større sammenhænge mellem teknologier, menneske og samfund. Fælles for digital dannelse og teknologiforståelse er således et ønske om at børn og unge via selvvirksomhed dannes til at forholde sig til teknologier i verden omkring dem.

Der er imidlertid også tale om forskelle mellem begreberne. Digital dannelse i en danskfaglig kontekst lægger vægt på adfærd og opførsel og bruges overvejende i forbindelse med børn og unges brug af sociale medier, computerspil og andre medier. Her er fokus ofte på kommunikation, adfærd og identitetsdannelse. Med fokus på digital 
myndiggørelse kommer teknologien derimod i forgrunden i undervisningen, idet der lægges op til at undersøge algoritmer og kunstig intelligens og deres betydninger. Resultatet er en anden og udvidet vinkel på dannelse i forhold til digitale teknologier, men det er uvist, hvordan denne vinkel skal realiseres inden for en danskfaglig optik. I læseplanen formuleres digital myndiggørelse snarere parallelt med dansk end som et bidrag til et eksisterende arbejde med elevernes dannelse.

\section{Et humanistisk frigørelsesperspektiv}

Det store fokus på teknologi og designfaglig tænkning i digital myndiggørelse er inspireret af både Paolo Freires og Paolo Bliksteins empowerment-begreb. Sidstnævnte er optaget af at gøre eleverne til forandringsagenter, som kan tænke kritisk om teknologi i verden, forandre den og dermed anvende teknologier til at adressere konkrete lokale behov, frem for en mere ureflekteret anvendelse at teknologier. Blikstein (2008) hævder fx, at de elever, han besøgte i sin forskning i Brasilien, som udgangspunkt er umyndige i forhold til teknologier, fordi det er teknologiernes indbyggede mekanismer, som styrer eleverne og ikke omvendt. Det er nok blandt andet i lyset heraf, at teknologifaglighedens lidt uklare begreb 'intentionalitet' skal ses. Begrebet er ellers klart defineret inden for fænomenologien og har de seneste hundrede år været brugt inden for filosofi om det forhold, at menneskets bevidsthed altid er rettet mod og altid allerede er engageret $i$ verden og optaget af fænomener. Dette brede begreb om intentionalitet reduceres med den nye teknologifaglighed til et spørgsmål om den intention, der fra producentens side er lagt ind i en given teknologis design. På den måde reduceres intentionalitet til et resultat af en rationel og målrettet handling. I den ordliste, der er udarbejdet af ministeriet som ledsager til forsøgsprojektet, hedder det således at:

99

Intentionalitet betegner de holdninger eller værdier, som designere har indlejret i et digitalt artefakt. Alle digitale artefakter sigter efter noget særligt eller har noget særligt til hensigt [...]. Den eller de mennesker, som har designet et digitalt artefakt, har således gjort det ud fra en intention, og artefaktet bærer dermed en intentionalitet.

(Caspersen \& Iversen, 2019, s. 10)

Der ligger således et dybt kritisk frigørelsesperspektiv i forsøgsprojektet, som relaterer sig til fagformålet om at forstå teknologiers rolle i et individ- og samfundsperspektiv. Derfor er det også ærgerligt, at man opererer med så snævert et begreb om intentionalitet. Menneskers 
Menneskers måder at forstå, handle og skabe i verden, sker altid i en social, kulturel og historisk situation og kontekst, der har betydning for værdier, valg og handlinger. Derfor vil et design og de affordances, der kendetegner dette design, altid være resultat af en lang række valg, handlinger, kulturelle værdier og historiske betingelser, som rækker ud over det enkelte menneskes rationelle måltænkning. Problemet med, at man ikke lykkes med at integrere en humanistisk faglighed i det aktuelle begreb om teknologiforståelse, kommer således særligt tydeligt til udtryk i den snævre definition af begreb intentionalitet, der afspejler en forestilling om, at man altid skaber produkter og herigennem forsøger at omskabe verden ud fra et rationelt menneskebillede.

\section{Digital sikkerhed}

Digital sikkerhed er skrevet ind i kompetenceområdet kommunikation i dansk, hvor der især arbejdes med elevers kommunikative og multimodale udtryk, og hvor elever skal lære at være skabende og aktive brugere af digital kommunikation. Sikkerhed er et færdighedsog vidensområde i faget teknologiforståelse under kompetenceområdet teknologisk handleevne. Digital sikkerhed er også et tværgående emne, som kommer til udtryk med underbegreber som "risici", "trusler", "sikker adfærd" og en generisk kompetence, som egner sig til at udfoldes i både samfundsfag, fremmedsprog og flere af de naturvidenskabelige fag. I dansk skal eleverne således:

\section{9}

[...] lære at begå sig sikkert i et virtuelt univers med særligt fokus på kommunikation. Det nye færdigheds- og vidensområde udvider begrebet digital sikkerhed ifm. kommunikation, herunder identifikation af trusler og risici samt viden om sikkerhedsmæssige aspekter ved færden i den digitale verden.

(UVM, 2019b, s. 7)

I danskfagets styredokumenter findes der ikke noget begreb om digital sikkerhed, så begrebsudvidelsen må stamme fra et andet fagligt domæne. Spørgsmålet er derfor, hvordan det skal kvalificeres og didaktiseres inden for en danskfaglig horisont. Et danskfagligt bud er, at digital sikkerhed ikke er en generisk og fagovergribende kompetence, men derimod et fænomen, der skal opleves og undersøges med afsæt i den måde, det fremtræder på i menneskets livsverden. Udfordringen er, at sikkerhed let bliver reduceret til et uvedkommende spørgsmål om teknikalitet og digital hygiejne. I dansk kan man alternativt tage fat i de eksistentielle og relationelle konsekvenser af brud på sikkerhed, 
der kan motivere beskæftigelsen med digital sikkerhed, da det som fænomen er forbundet med blandt andet angst, udsathed, tillid og mistillid, udnyttelse, magtrelationer og markedsgørelse. Der er således mange muligheder for at gøre det danskfagligt relevant, men de aktuelle målformuleringer gør det vanskeligt, da de er formuleret som en grammatik for sikker adfærd:

\section{Figur 1.}

Uddrag fra Færdigheds- og vidensmål i dansk for kompetenceområdet Digital handleevne.

Her lægges der vægt på teknisk viden og instrumentelle færdigheder.

Efter 4. klassetrin

\begin{tabular}{l|l|l} 
Digital sikkerhed & & \\
$\begin{array}{l}\text { Eleven kan identificere risikoadfærd i forbin- } \\
\text { delse med brug af digitale teknologier }\end{array}$ & $\begin{array}{l}\text { Eleven har viden om typiske risici ved brug } \\
\text { af digital teknologi }\end{array}$ & $\mathrm{X}$
\end{tabular}

Efter 6. klassetrin

\begin{tabular}{|l|l|l|l} 
& Digital sikkerhed & \\
\hline $\begin{array}{l}\text { Eleven kan forholde sig til sikker } \\
\text { adfærd ved brug af computere og } \\
\text { netværk i konkrete situationer }\end{array}$ & $\begin{array}{l}\text { Eleven har viden om hvordan } \\
\text { aktuelle, specifikke typer af trusler } \\
\text { fungerer }\end{array}$ & $X$ & $X$
\end{tabular}

Efter 9. klassetrin

\section{Digital sikkerhed}

Eleven kan handle sikkert og hensigtsmæssigt $\mathrm{i}$ interaktionen med digitale teknologier
Eleven har viden om sikkerhedsmæssige aspekter ved færden i den digitale verden

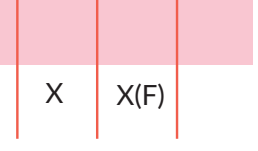

Denne del af teknologiforståelse kan karakteriseres som en digital version af det obligatoriske emne færdselslære. Man kan i forlængelse heraf spørge, om der er tale om en form for digital trafiksikkerhed, der ligesom de andre "timeløse fag" er vanskelig at integrere med fagene. Den didaktiske udfordring er, at læreplanen forholder sig til sikkerhed som et problem, der kalder på teknisk viden og instrumentelle færdi- 
heder, frem for at behandle det som et fænomen, man skal undersøge og fortolke med afsæt i enten egne erfaringer med at kommunikere i forskellige kontekster eller de fremmederfaringer, man kan få del i ved at beskæftige sig med æstetiske tekster. Digital sikkerhed og persondata forekommer derfor indtil videre som faglige fremmedelementer i dansk, og spørgsmålet er, hvor koblingen til eksisterende faglige begreber og fænomener skal findes, når det i læseplanen ikke er defineret, hvor begreber som "trussel" "sikkerhed" og "risiko" hører til?

\section{Sammenfatning - Styredokumenter for tekno- logiforståelse i dansk}

Vi har i analysen redegjort for, at teknologiforståelsesfagligheden i dansk medfører en terminologi, som i sagens natur dels er fremmed for danskfaget, og dels har brug for at blive didaktiseret og kvalificeret teoretisk, som det blev vist med de kritiske analyser af begreberne artefakt, intentionalitet og digital sikkerhed. Derudover beskrives fagligheden som en selvstændig delmængde, der skal integreres i dansk, hvilket lægger op til et større fagdidaktisk udviklingsarbejde.

Vilkårene er komplicerede, når styredokumenter skal udfærdiges uden en praksis at referere til eller et fagdidaktisk stillads at bygge på. Som vi har redegjort for, bærer læseplanen for dansk præg af, at det har været vanskeligt at komme ud over det generaliserende niveau. Analysen peger på, at alle tre kompetenceområder bør didaktiseres yderligere. I tilfældet digital myndiggørelse er der tale om en relativ snæver definition med teknologi som fokus og frigørelse som sigte. Analysen viste, at begrebet med fordel kan åbnes mod de humanistiske dannelsesaspekter, der i forvejen arbejdes med i begrebet digital dannelse i dansk.

Som det ses i beskrivelsen af teknologiforståelsesfagligheden, er det vanskeligt at pege på specifikke danskfaglige fænomener, genstande og stofområder, der kan fremhæves, som havende et særligt potentiale i forhold til teknologiforståelse. Dette kan forklares med, at man ikke i tilstrækkelig grad har formået at bringe social- og humanvidenskaberne i spil som basisfag, eller med tilpas tyngde vægtet den del af teknologiforståelsesfagligheden som trækker på den del af professionernes forståelse af teknologi, der ikke udspringer af STEM-tænkningen eller af et naturvidenskabeligt paradigme. Det er noget af dette, man må arbejde videre med.

\section{Eksempler fra undervisningsforløb i dansk}

I det næste afsnit vender vi os mod forløbene i afprøvningsforsøget, 
som har vores særlige interesse, fordi de integrerer de nye typer af faglige fænomener, indhold, stof, mål, faglige aktiviteter, metoder og generelle teknologifaglige refleksioner og overvejelser i faget. Vi vil med afsæt i to ekstreme cases give eksempler på de vanskeligheder, der opstår, når integrationen ikke helt lykkes. De to forløb er rettet mod henholdsvis $5 . \mathrm{kl}$ og 7 . $\mathrm{kl}$ og integrerer danskfaglige kompetenceområder og centrale faglige delelementer: Forløbet Kan man blive ven med en robot? (Godtliebsen, Nielsen, Kjær, Lorentzen \& Nissen, 2018) (herefter case A) integrerer således færdigheds- og vidensområder inden for kompetenceområderne fortolkning, læsning og kommunikation og teknologisk handleevne. I forløbet Dage med data-digitale fodspor og datasikkerhed (Nissen, Godtliebsen, Kiær, Lorentzen \& Nielsen, 2018-2021) (herefter case B) integreres bl.a. kompetenceområder for læsning, skrivning og fremstilling. De nye teknologifaglige elementer er datasikkerhed og digitalt selvforsvar, og målet er at udvikle elevernes kritiske sans i forhold til egen og andres digitale sikkerhed.

For at give et indtryk af, hvor vanskelig en opgave der er tale om, når strukturer i en fagtradition forstyrres og udfordres, koncentrerer vi os i analysen om de dele af forløbene, hvor det ikke lykkes at integrere teknologiforståelsesfagligheden.

I begge forløb er der arbejdet med at integrere teknologiforståelse som et egentligt nyt indhold: I forløbet Kan man blive ven med en robot skal eleverne læse fiktions- samt fagtekster om bl.a. venskab og om kunstig intelligens for til sidst i forløbet at udarbejde en teknologianalyse af en chatbot. En tillægsaktivitet er desuden, at elever i programmet Scratch selv skal skabe en chatbot. Denne sidste del af forløbet er set som ekstremcase den mest interessante del. Det viser sig, at chatbot som "skole-teknologi" i sig selv udgør, hvad man kan kalde for et ekstremt element, idet robottens svar på de spørgsmål eleverne stiller opleves som "upassende". Det gøres i forløbet (selvfølgelig) til en faglig pointe, fordi problemstillingen rammer lige ind i teknologiens intentionalitet og algoritmen, der teknisk set styrer robottens svar. Eleverne skal derfor diskutere følgende:

— Hvad det betyder, at en "intelligent" chatbots fremtidige svar cendres på baggrund af det, som folk har skrevet til den tidligere?

- I klassen diskuteres det, hvordan en chatbot bliver formet af de input, den får, og at dens svar ikke nødvendigvis knytter sig på en logisk måde til det spørgsmål, som man stiller.

(Godtliebsen, Nielsen, Kjær, Lorentzen \& Nissen, 2018, s. 13)

I case B er teknologiens skyggesider i centrum. Eleverne skal ikke skabe en teknologi, men udvikle et kritisk handleberedskab, som kan 
beskytte mod en uhensigtsmæssig, ja måske ligefrem farlig brug af teknologi. Forløbet er ekstremt i den forstand, at det sætter fokus på træk ved digital sikkerhed, der er vanskelige at knytte til konkrete situationer i en danskfaglig kontekst. Brud på den digitale sikkerhed kan have vidtrækkende etiske konsekvenser for det enkelte menneske. Det er en kendt problematik både i den politiske offentlighed og mange elevers livsverden, men et fokus på sikkerhed får let en udvendig og teknisk karakter, der indebærer, at koblingen til kommunikative erfaringer bliver overfladisk. Man kan fortælle, at der er risici forbundet med digital kommunikation, men det er vanskeligt at gøre de tekniske problemstillinger nærværende og kvalificere dem danskfagligt.

I lyset af, at der ikke er udviklet en fagdidaktisk begrundelse for, hvorfor og hvordan der kan arbejdes problembaseret med et robot-tema i dansk i 5. kl., illustrerer case A et andet ekstremt fremmedelement i danskfaget: Udfordringen ved at gøre programmering til et relevant afsæt for det litterære fortolkningsarbejde i dansk. Eller mere forløbsnært: Hvordan fagliggør man Scratch i dansk, hvilke begreber skal der til, og hvordan udvikler man mål, indhold og aktiviteter, som kobler elevers forforståelse af den litterære tekstanalyse til en teknologifaglig analyse af teknologi samt til det relevante i også selv at skulle programmere? Lad os se på, hvordan det er grebet an:

Som en del af litteraturarbejdet med kortromanen "Lige nu er allerede i morgen" introduceres eleverne for chatbotten Evibot/Boibot. Elevarbejdet er drevet af spørgsmål som: "Når man er mest ensom, kan man så bruge en chatbot som samtalepartner? Kan man tale om følelser med en robot? Kan man få sparring og vejledning af en robot" (Godtliebsen, Nielsen, Kjær, Lorentzen \& Nissen, 2018, s. 9).

Gennem afprøvning af chatbotten skal eleverne efterfølgende erfare chatbottens muligheder og begrænsninger. Teknologianalyse er en ny disciplin i dansk og derfor en ekstra grund til at forklare, hvad der er den faglige relevans bag: Eleverne skal undersøge og analysere Eviboten i forhold til, hvordan den er konstrueret, og hvilke værdier og betydninger, den tillægges. Eleverne skal ikke selv designe, men undersøge en teknologi, der er designet af andre. Det er forfriskende at lade elever undersøge en teknologi i en kortroman, for kan man faktisk gøre som hovedpersonen Felicia og bruge en chatbot som en fortrolig samtalepartner? Kan man være i dialog med en maskine? Samtidig kunne man med begrebet "fradigtning" (Hansen, 2004) pege på, at et øget teknologifokus medfører en variant af fradigtning, idet elevens tekstarbejde ikke foregår som en nærlæsning af teksten. En yderligere komplikation er, at begreber som konsekvensanalyse og analyse-kanvas mv. ikke umiddelbart kobler til gængse danskfaglige analytiske 
men at eleverne selv kan bestemme den rækkefølge, de arbejder med analysemodellens elementer" (Godtliebsen, Nielsen, Kjær, Lorentzen \& Nissen, 2018, s. 12).

Det analytiske abstraktionsniveau, som elever skal mestre i forløbet, er højt, og det forbinder flere perspektiver; de skal fastholde en litterær analyse, magte en helt ny type af teknologifaglig analyse og måske også snuse til et programmeringssprog. I det omfang, det lykkes, er det, fordi der igennem hele forløbet holdes fast i grundspørgsmålet: "Hvordan og hvorfor Eviebot fungerer eller ikke fungerer som en ven, fortrolig og samtalepartner" (s. 12).

Ud fra et fagdidaktisk perspektiv må man spørge til, om og hvordan en chatbot repræsenterer en fagligt relevant problematik, der passer ind i det ensomhedstema, som eleverne arbejder med. Hvad er formålet med at bringe robotten ind i undervisningen?

Et bud på et svar er, at robotten kan være med til at kaste lys over, hvad der tæller som en tekst i dansk. Robotten er netop ikke en tekst med et budskab, men en tegnproducerende teknologi, der kan bruges til at replicere data. Af samme grund er teknologiens intentionalitet af en anden art end intentionalitet i en tekst, der fremstiller et indhold. Spørgsmålet er, om en chatbot egentlig ikke mangler intentionalitet i danskfaglig forstand, og nærmere må ses som en designfaglig mulighed - et potentiale. Det vil i så fald betyde, at den kun er relevant at inddrage, hvis robotten kan aktiveres som et perspektiv på andre relevante danskfaglige fænomener og temaer, det vil i dette tilfælde sige romanteksten og temaet menneske/maskine.

I forløbet lægges der vægt på, at eleverne skal udvikle og afprøve deres kompetencer til at: "analysere, diskutere og reflektere over, hvordan teknologien er designet af nogle med en intention" (Godtliebsen, Nielsen, Kjær, Lorentzen \& Nissen, 2018, s. 10). Det er forudsætningen for, at de efterfølgende kan gennemføre en teknologianalyse, hvor de arbejder med scenariet med hovedpersonen Felicia og hendes møde med Eviebot.

Teknologi er dermed ikke kun afsæt for analyse, men bliver også til en velkendt og relevant tematik og problemstilling i en humanistisk tekstfortolkende tradition som fx: Hvad er et menneske? Hvad er en maskine? Kan man gøre maskiner menneskelige? Kan man gøre mennesker maskinagtige? og Hvad sker der i mødet mellem menneske og maskine? Tematikken er ikke ny og bliver eksempelvis tematiseret i fiktive fortællinger som Svend Åge Madsens "Som skabt for hinanden", Sara Engells "21 måder at dø på" og Niviaq Korneliussens "HOMO Sapienne" (Henkel, 2016, s. 80). Det nye er, at der i casen tages udgangspunkt i teknologien, og hvordan den fungerer. Den fagdidaktiske intention med forløbet er at opbygge elevers forestillingskraft og skærpe deres kritiske sans ved at lægge op til spekulation over mulige 
dilemmaer i mødet med robotter. Ved at forholde sig til disse teknologiske fænomener lærer elever at forholde sig til spørgsmål, som de ikke kender svaret på, fordi det ikke findes endnu. Samtidig lægger temaet menneske versus maskine op til at arbejde med den historiske dimension, som ikke er tænkt ind i den nye faglighed. Problematikken har nemlig en lang virkningshistorie, der har betydning for computere og robotters udvikling.

I dansk er det problematisk at løsrive fænomener fra deres historiske kontekst og kompleksitet. Derfor peger den litterære tilgang på behovet for, at den teknologididaktiske udvikling skal integreres med eller udvides til at omfatte en humanistisk dimension, således at der udvikles en litterær, fænomenbaseret teknologididaktisk retning, som i højere grad har fokus på begreber som teknologisk forestillingskraft, og på hvordan man eksempelvis kan udvikle fantasi ved at arbejde med at læse og skrive, uden at det foregår i tilknytning til en nyttebaseret kompleks problemstilling (Paaskesen \& Nørgaard, 2016). En fagdidaktisk udvikling med afsæt i litteratur som fænomen kan til forskel herfra rammesætte en æstetisk kompleksitet, hvor litteratur og fagets metoder bidrager til at udvide teknologianalysen. Litteratur er i den henseende et eksistentielt eksperimentarium for mulige sammenvævninger af mennesker og maskiner, der klart kan bidrage til at udvide teknologiforståelsens horisont, der ellers let lader sig reducere til en kausalt determineret og som følge heraf fantasiforladt instrumentalisme. Den æstetiske tekstanalyse er så central i dansk, at et stærkere fokus på læsning og fortolkning vil være en oplagt udvidelse og kvalificering af videns- og færdighedsmålene for kommunikation, fortolkning og fremstilling, som i den nuværende læseplan er afsæt for integration af den nye faglighed.

\section{Digital fabrikation og teknologianalyse}

Med afsæt i målet, at elever "skal fremstille med digitale teknologier samt få en forståelse af digitale teknologier som byggemateriale, der kan bruges til at eksternalisere tanker" (UVM, 2019b, s. 10) skal eleverne i forløbet især opnå indblik i et digitalt computersprogs begrænsninger. Afsættet i kodning i Scratch kan måske give elever en større forståelse for, hvordan det menneskeskabte sprog indeholder en anden kompleksitet i sammenligning med programmeringssprog. Men med forløbet ser vi også tegn på, at teknologifagligheden i dansk giver mulighed for at arbejde med det computationelle kompetenceområde. Derved bliver det muligt at konkretisere og bearbejde en teknologisk problematik, hvor eleverne på baggrund af erfaringer med programmering (Scratch) opfordres til at stille teknologisk fantasiful- 
de spørgsmål til kommunikative problemer: "I klassen diskuteres det, hvordan en chatbot bliver formet af de input den får, og at dens svar ikke nødvendigvis knytter sig på en logisk måde til det spørgsmål, som man stiller" (Godtliebsen, Nielsen, Kjær, Lorentzen \& Nissen, 2018, s. 13). Men som vist tidligere er det også en faldgrube, fordi både elever og lærer skal have et multifaceteret analytisk beredskab for at kunne lykkes med denne del.

Forløbet inkorporerer en række inkommensurabiliteter i dansk, hvor fx den teknologifaglige fremstilling og analyse er vanskelig at integrere i den litterære analyse. Særlig opmærksomhed påkalder en elevaktivitet, hvor elever skal skabe fiktive dialoger i chatbotten. Formålet er at finde sammenhænge mellem det digitale artefakts formål, intentionalitet og anvendelsesmuligheder, idet eleverne analyserer "Eviebot", som andre har designet med en intention om en bestemt anvendelse. De skal afkode teknologien og med forskellige analysegreb undersøge intentionen bag målgrupper, indhold mv. I teknologiforståelsesfagligheden betyder det, at de skal lære at forstå teknologiens konstruktion ved selv at kunne bygge noget, og her overskrides kompetenceområderne, da computationel tænkning som nævnt ikke er en del af fagligheden i dansk. Som analysen viser, kan det destabilisere gængse strukturer, når begreber som teknologianalyse, formålsanalyse, brugsstudier og konsekvensvurdering skal integreres (UVM, 2019b, s. 7). Teknologianalyse er således en ny analytisk disciplin i dansk, hvor der skal udvikles relevant indhold, som kan kobles til en danskfaglig teknologididaktik (Hansen, 2020). Et centralt spørgsmål i denne søgen efter indhold bliver, hvilke fænomener der egner sig som midler i en designproces med det formål, at eleven lærer at forstå digitale teknologier.

\section{Digital sikkerhed og risiko i dansk}

Et andet indholdsområde, der på lignende vis er under opbygning, er færdigheds- og vidensområdet digital sikkerhed, som er knyttet til kompetenceområdet kommunikation i dansk og kompetenceområdet teknologisk handleevne i faget teknologiforståelse. I forløbet Dage med data - digitale fodspor og datasikkerhed arbejdes der med datasikkerhed og digitalt selvforsvar med henblik på at udvikle elevernes kritiske sans i forhold til egen og andres digitale sikkerhed. Problemstillingen lyder: "Hvordan informeres unge i aldersgruppen bedst om digital sikkerhed? Forslag til alternativ: Hvordan lærer unge om de udfordringer og potentielle farer, som eksisterer i forbindelse med digital sikkerhed, når de færdes på nettet?” (Nissen, Godtliebsen, Kiær, Lorentzen \& Nielsen, 2018-2021, s. 8). 
og potentielle farer, som eksisterer i forbindelse med digital sikkerhed, når de færdes på nettet?" (Nissen, Godtliebsen, Kiær, Lorentzen \& Nielsen, 2018-2021, s. 8).

Forløbet har altså et hovedspor, hvor målet er, at eleverne opnår viden om, hvad det vil sige at give et samtykke, herunder datadeling med fx virksomheder, der tilbyder browsere, søgemaskiner, hjemmesider mv., samt hvilke risici der er forbundet med at dele data med tredjepartsfirmaer. Eleverne skal gennem denne del af forløbet blandt andet forholde sig til egne persondata, og hvordan man kan udvikle et digitalt "selvforsvar". Elevaktiviteten er ikke forbundet til en tekst eller tekstarbejde, men koblet til netop at informere og få forklaret. I denne del af forløbet indarbejdes en række ord og begreber, som eleverne nok har hørt, men måske ikke kender betydningen af, fx: serverlogfiler, Virtual Private Network, Pixeltag, Digital Subskriber Line og selvfølgelig EUs Persondatalov, GDPR. I et mindre fagligt sidespor skal eleverne arbejde med fiktionstekster, som tematiserer, hvad data er iagttaget som et fagligt fænomen. Eleverne skal se videoen: "Hvis din bagerjomfru var en app" og lytte til et uddrag af romanteksten "Alt er data” af Lone Hørslev og Jesper Mechlenburg (Nissen, Godtliebsen, Kiær, Lorentzen \& Nielsen, 2018-2021, s. 9).

Herefter skal eleverne arbejde med, at der er flere betydninger i en tekst i følgende rammesætning: "Hvor mange betydninger kan der ligge i sætningen: "vi forærer det væk" (...) det faktum, at jeg ik kan sige nej, til dig".? Hvad er det, vi forærer væk? Og hvor forærer vi det væk?" (Nissen, Godtliebsen, Kiær, Lorentzen \& Nielsen, 2018-2021, s. 9).

I hovedsporet er det dog den faktuelle og informationsbaserede tilgang, som er stærkt styrende for elevernes arbejde. De skal bl.a. lære at handle sikkert på nettet, hvilket skal udfolde sig i en filmproduktion om, hvordan internettet fungerer, hvad digitale fodaftryk er, hvordan vores data bliver overført, og hvordan man kan beskytte sig mod trusler og samtidig begå sig sikkert på nettet (Nissen, Godtliebsen, Kiær, Lorentzen \& Nielsen, 2018-2021, s. 4). Også elevernes egne digitale fodspor inddrages, så brug og afgivelse af data bliver helt konkret: "Under arbejdet med de digitale fodspor er det vigtigt at spore eleverne ind på, at det ikke kun er telefonen, der sætter digitale fodspor - Rejsekortet, Sygesikringskortet, skoletandlægen, lægen, Aula indsamler også data om eleverne" (Nissen, Godtliebsen, Kiær, Lorentzen \& Nielsen, 20182021, s. 10).

Som det fremgår, knytter elevarbejdet ikke tydeligt an til konkrete kommunikationssituationer eller fortolkende tekstarbejde, men til basale betingelser og samfundsmæssige problemer i relation til kommunikativ adfærd og kommunikationsetik, hvilket giver anledning til at diskutere, hvilken toning eller genfortolkning digital sikkerhed skal have for at kunne integreres i et danskfagligt kompetenceområde. 
Som vi tidligere har været inde på, udfolder læreplanen digital sikkerhed som et problemfelt, der kalder på teknisk viden og instrumentelle færdigheder, men det behandles ikke som et fænomen, elever skal undersøge og fortolke med afsæt i enten egne erfaringer med at kommunikere i forskellige kontekster eller de fremmederfaringer, man kan få del i ved at beskæftige sig med æstetiske tekster. Derfor er det stadig et uafklaret spørgsmål, hvilke danskfaglige begreber, der knytter sig til disse områder.

Hvis vi holder fast $\mathrm{i}$, at teknologiforståelse skal give mening inden for enten en æstetisk-fortolkningsmæssig eller praktisk-kommunikativ tilgang til tekster i meningsfulde situationer, er der mange elementer i dette forløb, som ganske enkelt bliver svære at løfte ind i faget. Det må derfor bero på en vurdering, om videns- og færdighedsmålet digital sikkerhed under kompetenceområdet teknologisk handleevne kan udvikles til at blive et relevant fagligt element i dansk. I læseplanen er de faglige argumenter for relevansen af teknologisk handleevne i dansk ikke formuleret tydeligt, og det er et åbent spørgsmål, om danskfagets aktører selv kan og vil tage området til sig (eller på sig), eller om digital sikkerhed i stedet vil blive behandlet som et tværgående tema. Uanset hvad vurderer vi på baggrund af såvel de udvalgte cases som de andre prototyper i forsøget, at det vil kræve en del didaktisk udvikling at kvalificere temaet og motivere eleverne til at arbejde med sikkerhedsproblematikken i relation til problemstillinger, der giver mening både fagligt og eksistentielt i relation til elevernes livsverden. Udfordringen er ikke særskilt for dansk, men mere generel, da spørgsmålet om sikkerhed let bliver et spørgsmål om specifik teknik eller abstrakte betingelser for produktion, brug og udveksling af data.

\section{Diskussion: Teknologiforståelse som udvidelse eller faglig forandring}

Denne artikels empiriske grundlag har været en brøkdel af de forløb, som er produceret i dansk og har eksemplificeret den nye fagligheds udfordringer og betingelser i dansk i afprøvningsforsøget. Det samlede indtryk er, at det er en vanskelig øvelse at integrere denne aktuelle formulering af teknologiforståelse som faglighed på en måde, så kernen bevares i den eksisterende danskfaglighed, samtidig med at både fag og teknologiforståelsesfaglighed udvikles. Det rejser et spørgsmål om, hvorvidt teknologiforståelsesfagligheden blot skubber til eksisterende faglighedsforståelser, eller om den har potentiale til at forandre faget til et anderledes danskfag, der arbejder med tilhørende nye teknologifaglige fænomener. Indtil videre har vi kunnet iagttage tegn på en 
udvikling af fagets genstandsfelt og metoder og ikke en væsensmæssig forandring. Der tilbagestår stadig et behov for mere systematisk at undersøge, om og hvordan elever kan arbejde med computationel tankegang i spændingsfeltet mellem danskfaglige og teknologiforståelsesfaglige fænomener og begreber, og hvordan teknologiforståelse konkret kan påvirke og eventuelt også være med til at forandre fagets praksis. Den problembaserede tilgang kalder på fagdidaktiske overvejelser omkring forholdet mellem det fænomen- og det problembaserede, herunder især hvordan det problembaserede kan kobles til elevers forforståelse og forholdet mellem indhold og elevernes subjektivt oplevede erfaringer som et bidrag til elevers forståelse af deres omverden.

Endelig kalder færdigheds- og vidensmål for digital myndiggørelse på nærmere overvejelser over, hvordan teknologier didaktisk kan inddrages som genstandsfelt i faget, så der både gives mulighed for analytisk indblik og kritisk refleksion i et fag, som hovedsageligt har tradition for at beskæftige sig med det digitale i form af tekster. Som beskrevet kan digital myndiggørelse bruges som anledning til at udvikle tilgangen til digital dannelse i danskfag. Hvis det lykkes at udfolde en sådan analytisk og kritisk tilgang, der samtidig giver plads til at stimulere elevernes fantasi, øjner vi en mulighed for, at dansk som et humanistisk dannelsesfag kan befrugte teknologiforståelsesfagligheden, der som påpeget overvejende udspringer af en STEM-tradition.

I alle forløb er der tale om en udvidelse af det faglige sprog i forsøget på at gribe teknologiforståelsesfagligheden på fagets præmisser. I et længerevarende perspektiv kræver det dog mere tid at udpege de begreber, som kan opbygge den indholdsmæssige klarhed og konsistens, som er nødvendig for at udarbejde en egentlig praksis for teknologianalyse, brugsstudier osv.

Fag flytter på sig, når nye sproglige og domænespecifikke begreber rykker ind, men hvad langtidseffekterne er i et fag, når nye ord og begreber bryder ind i eksisterende begrebshierarkier, er en ubekendt størrelse. 


\section{Referencer}

Bundsgaard, J., Petterson, M. \& Puck, M.R. (2014). Digitale kompetencer. It i danske skoler $i$ et internationalt perspektiv. Aarhus Universitetsforlag.

Bundsgaard, J., Bindslev, S. Caeli, E. N. Pettersson, M, Rusmann. A. (2019). Danske elevers teknologiforståelse. Resultater fra ICILS-undersøgelsen 2018. Aarhus Universitetsforlag.

Bundsgaard, J. (2017). Digital dannelse. Aarhus Universitetsforlag

Blikstein, P. (2008). Travels in Troy with Freire: Technology as an agent for emancipation. I: C. A. Torres \& P. Noguera (red.), Social Justice Education for teachers: Paulo Freire and the Possible Dream. Sense.

Caspersen, M. E., Iversen, O. S., Nielsen, M., Hjorth, A. \& Musaeus, L. H. (2018). Computational Thinking - hvorfor, hvad og hvordan? It-vest - samarbejdende universiteter.

Caspersen, M. E. \& Iversen, O. S. (2019). Ordliste over fagbegreber $i$ teknologiforståelse ifolkeskolen. Børne- og Undervisningsministeriet.

Caspersen, M. E., Iversen, O. S., Nielsen, M., Hjorth, H. A. \& Musaeus, L. H. (2018). Computational Thinking - hvorfor, hvad og hvordan? https://it-vest.dk/ fileadmin/user_upload/pdf/2018-12-18--Computational-Thinking--hvorfor-hvadog-hvordan--PRINT-2-sided.pdf

Caeli, E. N. \& Bundsgaard, J. (2019). Datalogisk tænkning og teknologiforståelse i folkeskolen tur-retur. Tidsskriftet Loering og Medier (LOM), 11(19), 30. https://doi. org/10.7146/lom.v11i19.110919

Colucci-Gray, L., Burnard, P., Cooke, C., Davies, R., Gray, D. \& Trowsdale, J. (2017). Reviewing the potential and challenges of developing STEAM education through creative pedagogies for 21st learning: how can school curricula be broadened towards a more responsive, dynamic, and inclusive form of education? A report from one of the BERA Research Commissions.

Creswell, J. W. (2008). Grounded Theory Designs. I: Educational Research (3. udg.). Pearson.

Engeström, Y. (1987). Learning by Expanding: An Activity-Theoretical Approach to Developmental Research. Orienta-Kulsutit.

Elf, N. (2017). Medier, tekst og tegn i dansk. I: E. Krogh, N. Elf, T. Høegh \& H. Rørbech (red.). Fagdidaktik $i$ dansk. Frydenlund.

Flyvbjerg, B. (2010). Fem misforståelser om casestudiet. I: Kvalitative metoder (s. 463-487). Hans Reitzels Forlag.

Gadamer, H.-G. (2007). Sandhed og metode. Hans Reitzels Forlag.

Godtliebsen, A., Nielsen, L., Kjær, K., Lorentzen, R. F. \& Nissen, A. (2018). Kan man vore ven med en robot? Kan downloades fra Forsøg med teknologiforståelse: https://tekforsøget.dk/wp-content/uploads/202o/o6/chatbot-5.kl_.dansk-26-06-20.pdf

Goodlad, John, Klein, M. F. \& Tye, K. A. (1979). The Domains of Curriculum and Their Study (s. 43-76). I: Curriculum inquiry: The study of curriculum practice. McGraw-Hill.

Gruschka. A. (2016). At loere at forstå. Forlaget Klim.

Hasse, C. (2016). Teknologiforståelse i et kulturperspektiv. Learning Tech. Tidsskrift for loeremidler, didaktik og teknologi, (1), 99-114. Læremiddel.dk. 
Hansbøl, M. \& Ejsing-Duun, S. (2017). Hovedrapport: Coding Class. Dokumentation og evaluering (rapport). Hentet den 13. april på: https://itb.dk/wp-content/ uploads/2018/12/rapport--coding-class-dokumentation-og-evaluering-endelig.pdf

Hansen, T. I. (2004). Procesorienteret litteraturpcedagogik. Dansklærerforeningen.

Hansen, T. I. (2013). Mellem hermeneutik og kommunikation - Et bud på en holistisk fortolkning af tekst, genrer, teksttyper og tekstkompetencer i dansk. I: H. Rørbæk (red.), Cursiv nr. 12: Didaktiske destinationer. Aarhus Universitetsforlag.

Hansen, T. I. (2019). Teknologiforståelse som praktisk klogskab - Om variation og virksomhedsformer i teknologiforståelse som fag. Unge pcedagoger. Tema: Teknologiforståelse på skemaet.

Hansen. T. I. (2015). Dansk. Forlaget Klim.

Henkel, A. Q. (2016). Ungdomslitteratur former(er) sig. Passage - Tidsskrift for Litteratur Og Kritik, 31(75). https://doi.org/10.7146/pas.v31i75.24167.

ITEA. (2000/2007). Standards for Technological Literacy: Content for the study of technology. Hentet den 12. april 2021 på: www.iteaconnect.ora/TAA/PDFs/xstnd. pdf

Krogh, E. Qvortrup, A. \& Christensen. T. S. (2016). Almendidaktik og fagdidaktik. Frydenlund.

Køhrsen, L. \& Gissel, S. T. (2020). Teknologiforståelse og genreundervisning i dansk i indskolingen. Unge poedagoger. Tema: Teknologiforståelse på skemaet.

Ihde, D. (2010). Heidegger's technologies. Fordham University Press.

Ingerman, A. \& Collier-Reed, B. (2011). Technological literacy reconsidered: a model for enactment. International Journal of Technology and Design Education, 21(2), 137-148.

Iversen, O. I., Dindler, C. \& Smith, R. C. (2019). En designtilgang til teknologiforståelse. Dafolo.

Nissen, A., Godtliebsen A., Kiær, K., Lorentzen, R. F. \& Nielsen, L. (UVM). (20182021). Dage med data - Digitale fodspor og datasikkerhed (prototype). UVM: https://xn--tekforsget-6cb.dk/wp-content/uploads/2020/o9/Datasikkerhed-7. kl-dansk-15.09.20.pdf

Paaskesen, R. B. \& Nørgaard, R. T. (2016). Designtænkning som didaktisk metode: Læringsdesign for teknologisk forestillingskraft og handlekraft. Loring \& Medier (LOM), 16 .

Rambøll. (2019). Forundersøgelse - Forsøg med teknologiforståelse ifolkeskolens obligatoriske undervisning. Hentet den 12. april 2021 på: https://xn--tekforsget$6 \mathrm{cb.dk} /$ vidensgrundlag/forundersoegelse/

Rentorff, I. (2015). Lige nu er allerede i morgen. Gyldendal.

Smith, R. C., Iversen, O. S. \& Hjorth, M. (2015). Design Thinking for Digital Fabrication in Education. International Journal of Child-Computer Interaction, 5 , 20-28. DOI:10.1016/j.ijcci.2015.10.002

Säljö, R. (2005). Lärande \& kulturelle redskab. Om lärprocesser och det kollektive minnet. Nordstedts Akademiska Forlag.

van den Akker, J. (2003). Curriculum Perspectives: An Introduction. I: J. van den Akker, W. Kuiper \& U. Hameyer, Curriculum Landscapes and Trends. Kluwer Academic Publishers. 
Wagner, M. L., Iversen, O. S. \& Caspersen, M. (2020). Teknologiforståelsens rationale: På vej mod computationel empowerment i den danske grundskole. Unge poedagoger. Tema: Teknologiforståelse på skemaet.

Technucation. (n.d.). Teknologiforståelse. Hentet den 12. april 2021 på: https:// technucation.dk/begreber-og-fokusomraader/teknologiforstaaelse/

Teknologiforståelse i folkeskolen. (2019-2021). https://tekforsøget.dk/om-forsoget UVM. (2018). Undervisningsvejledning for forsøgsfaget teknologiforståelse . Publikationen kan hentes på EMU.dk.

UVM. (2019a). Dansk. Måloversigt. Hentet den 12. april 2021 på: https://emu.dk/sites/ default/files/2019-02/7568_STIL_M\%C3\%A5l_Dansk_web_FINAL-a.pdf

UVM. (2019b). Tilføjelse til loeseplan $i$ dansk. Forsøgsprogrammet med teknologiforståelse. Hentet den 12. april 2021 på: https:/emu.dk/sites/default/ files/2019-02/7592_Bilag_L\%C3\%A6seplan_Dansk_web_FINAL-a.pdf 